\title{
Is the Market a Sphere of Social Freedom?
}

\author{
TIMO JÜTTEN \\ School of Philosophy and Art History, University of Essex, UK
}

In this paper I examine Axel Honneth's normative reconstruction of the market as a sphere of social freedom in his 2014 book, Freedom's Right. Honneth's position is complex: on the one hand, he acknowledges that modern capitalist societies do not realize social freedom; on the other hand, he insists that the promise of social freedom is implicit in the market sphere. In fact, the latter explains why modern subjects have seen capitalism as legitimate. I will reconstruct Honneth's conception of social freedom and investigate how it is realized in the sphere in which Honneth sees it most successfully at work, the sphere of interpersonal relations. I then move on to the sphere of the market economy and discuss two related problems of this view that stem from his interpretation of Hegel. Next, I consider Honneth's method of "normative reconstruction" and his reconstructions of the sphere of consumption and, finally, the labor market. My conclusion will be that market institutions cannot realize social freedom, and that this insight should orient the philosophical direction of critical social theory.

KEYWORDS Axel Honneth, critical social theory, markets, capitalism, freedom, G.W.F. Hegel

\section{Introduction}

According to Axel Honneth, the claim that the market is a sphere of social freedom, rather than merely of negative freedom, goes back at least as far as Adam Smith's Wealth of Nations (1776). It receives its most ambitious defence in Hegel's Philosophy of Right (I82I), and recently has been reinvigorated in Honneth's monumental reworking of the Philosophy of Right in his book, Freedom's Right: The Social Foundations of Democratic Life. ${ }^{\mathrm{I}}$ To say that the market is a sphere of negative freedom is to say that it offers market participants the

\footnotetext{
I Axel Honneth, Freedom's Right: The Social Foundations of Democratic Life, trans. Joseph Ganahl (Cambridge: Polity, 20I4); originally published as Das Recht der Freiheit: Grundriß einer demokratischen Sittlichkeit (Berlin: Suhrkamp, 20II). 
freedom to enter into contracts about the exchange of goods and services on the basis of their individual preferences and on mutually agreed terms. To say that the market is a sphere of social freedom is to say that it is a sphere of social action in which individual actors "complete each other" in the sense that the satisfaction of others' desires is a precondition of the satisfaction of their own. The mutual recognition of mutual dependency is a form of freedom, because individual actors recognize in the institutions of the market the mechanisms through which the satisfaction of everyone's desires becomes possible. The purpose of this paper is to examine whether Honneth's argument in Freedom's Right is plausible. To this end I will raise some doubts about whether the market is best understood as a sphere of social freedom.

Honneth does not commit himself to the implausible view that markets in today's capitalist societies are in fact spheres of social freedom. However, he does suggest that the promise of social freedom is implicit in the institutions of the market, and that this promise explains the legitimacy of the market in the eyes of market participants. On the basis of this suggestion a critical theory of society can diagnose deviations from the promise that is implicit in the institution of the market as misdevelopments that plague today's capitalist societies. In order to evaluate Honneth's argument it will be necessary to probe this suggestion: how plausible is it that the promise of social freedom is implicit in the institutions of the market, and that capitalism as we know it is a deviation from this promise, rather than an expression of the very nature of capitalism? While the purpose of this paper is to evaluate Honneth's argument, the answer to this question clearly has wider implications for our ethical assessment of market societies and the political strategies that we should adopt in criticizing their shortcomings.

I begin my argument with a discussion of social freedom in Hegel and Honneth (II), before moving on to a closer examination of the terminology of "completion" (III). Next, I consider Honneth's claim that the market is a sphere of social freedom (IV) and discuss two related problems of this view that stem from his interpretation of Hegel (V). I then move on to Honneth's method of "normative reconstruction" and his reconstructions of the sphere of consumption (VI) and, finally, the labor market (VII-VIII). My conclusion will be that market institutions cannot realize social freedom, and that this insight should orient the philosophical direction of critical social theory (IX).

\section{Honneth on social freedom}

Honneth adopts the term "social freedom" from Frederick Neuhouser, who uses it to characterize Hegel's conception of freedom in the sections on Sittlichkeit in the Philosophy of Right. ${ }^{2}$ Neuhouser writes that social freedom is "a distinctive species of freedom that can be realized only by and within certain social institutions, most notably, those Hegel takes to be the three central institutions of modernity," that is,

\footnotetext{
${ }^{2}$ Honneth, Freedom's Right, 43.
} 
the family, civil society and the state. ${ }^{3}$ Like Neuhouser, Honneth stresses that social freedom has a subjective and an objective component. It is not enough that subjects can act on their intentions (personal freedom) or form their intentions freely (moral freedom); rather "the external, social reality must be able to be conceived as being free of all heteronomy and compulsion." " Whereas personal and moral freedom are conceived against an external reality that is indifferent to our volition, social freedom requires that the social institutions in which we act be free, too, in the sense that they enable us to realize our freedom in and through others who share our aims.

According to Honneth, social freedom is closely related to the experience of mutual recognition, and he sees the key to both concepts in Hegel's remarks about friendship and love in the Philosophy of Right, where he characterizes freedom as being "with oneself in the other." 5 We are free in friendship and love because we see the other not as a limitation of our own freedom but as its precondition. Honneth uses the terms complementarity, confirmation and "need for completion [Ergänzungsbedürftigkeit]" in order to express this Hegelian conception of freedom based on mutual recognition. He writes:

The striving for freedom no longer forms an element of merely subjective experience as soon as we encounter other subjects whose aims complement our own. ${ }^{6}$

In the first instance, therefore, 'mutual recognition' merely refers to the reciprocal experience of seeing ourselves confirmed in the desires and aims of the other, because the other's existence represents a condition for fulfilling our own desires and aims. ${ }^{7}$

Once both subjects recognize the need to complete [Ergänzungsbedürftigkeit] their respective aims, thus seeing their own aims in the other, merely reflexive freedom becomes intersubjective freedom. ${ }^{8}$

This account of social freedom as a "need for completion" seems plausible where friendship and love are concerned. According to Honneth's reconstruction of modern practices of friendship and love in Freedom's Right, "modern friendship enables us to experience our own will as something whose articulation is desired by a concrete other." Such friendship is "free from instrumental considerations," Io and, therefore, "the normative rules of friendship ensure today that two individuals complete each other within the framework of friendship by bearing trustworthy witness to the existential decisions of the other and by providing advice."II In romantic love an intense form of friendship is coupled with sexual intimacy and physical closeness, and with a commitment to a shared future. As a result,

\footnotetext{
${ }^{3}$ Frederick Neuhouser, Foundations of Hegel's Social Theory: Actualizing Freedom (Cambridge, MA: Harvard University Press, 2000), 6.

${ }^{4}$ Honneth, Freedom's Right, 44.

5 G.W.F. Hegel, Elements of the Philosophy of Right, ed. Allen W. Wood (Cambridge: Cambridge University Press, I991), §7 A.

${ }^{6}$ Honneth, Freedom's Right, 44.

7 Honneth, Freedom's Right, 44-5.

${ }^{8}$ Honneth, Freedom's Right, 45, translation modified.

9 Honneth, Freedom's Right, I40.

to Honneth, Freedom's Right, I4I.

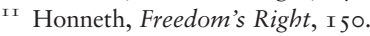


[t]he two individuals supplement and complete each other not only by promoting and supporting each other's ethical formation, but also and especially by satisfying each other's physical needs, which each views as especially important for their own vitality and well-being. Therefore, in the social form of love as we know it today, each person is a condition for the freedom of the other by becoming a source of physical selfexperience for the other. ${ }^{\mathrm{I} 2}$

However, Honneth's account of social freedom seems less plausible where the institutions of the market economy are concerned.

\section{Social freedom as completion}

To see this, it is useful to reflect on the terms "completion [Ergänzung]" and "need for completion [Ergänzungsbedürftigkeit]," which are central to Honneth's analysis of social freedom. They do not originate in Hegel, but in Marx's "Comments on James Mill” (I 844). In this text Marx contrasts two ways in which we can complete each other, that is, in which we can cooperate with one another in order to meet our needs. Either we meet our needs through market exchange or we produce "as human beings," ${ }^{\mathrm{3} 3}$ that is to say, as we would produce in a communist society. According to Marx, when we meet our needs through market exchange, "[ $\mathrm{t}]$ he social relation in which I stand to you, my labor for your need, is ... a mere semblance, and our complementing each other [unsere wechselseitige Ergänzung] is likewise a mere semblance ..." ${ }^{4}$ By contrast, in communist production we genuinely are completing each other. I realize myself through my production, and, at the same time, I help you meet your need. As Marx puts this point, I "would become recognised and felt by you yourself as a completion of your own essential nature [Ergänzung deines eignen Wesens] and as a necessary part of yourself, and consequently would know myself to be confirmed both in your thought and your love." 5

The form of completion that Marx criticizes as mere semblance is the very weak form of completion that can be found in Adam Smith's Wealth of Nations. According to Smith, commercial society has the potential to bring about universal opulence and eliminate poverty, because its complex division of labor increases the productivity of labor to a degree that makes the satisfaction of everyone's needs possible. As is well known, Smith thinks that this division of labor is not the result of "human wisdom," but of the human "propensity to truck, barter, and exchange one thing for another." ${ }^{6}$ Individuals specialize in the production of specific products and trade in them, rather than trying to meet all their needs themselves, because it is more productive and more profitable, but the result is an overall increase in social productivity. Hence, the individual:

\footnotetext{
${ }^{\mathrm{I} 2}$ Honneth, Freedom's Right, I 5 I.

${ }^{13}$ Karl Marx, "Comments on James Mill, Éléments D'économie Politique," in Karl Marx/Friedrich Engels, Collected Works (New York: International Publishers, I975), vol. 3, 227.

${ }^{14}$ Marx, "Comments on James Mill," 226.

${ }^{15}$ Marx, "Comments on James Mill," 228.

${ }^{16}$ Adam Smith, An Inquiry Into the Nature and Causes of the Wealth of Nations, ed. R.H. Campbell and A.S. Skinner (Indianapolis, IN: Liberty Fund, I976), Vol. I, Bk I, Ch. 2, 25.
} 
intends only his own gain, and he is in this, as in many other cases, led by an invisible hand to promote an end which was no part of his intention. Nor is it always the worse for the society that it was no part of it. By pursuing his own interest he frequently promotes that of the society more effectually then when he really intends to promote it. ${ }^{17}$

Commercial society seems to be a sphere in which individuals complete each other, then, because the self-interested behaviour of one individual satisfies the needs of another and vice versa.

Marx initially criticizes this form of completion, because he thinks that it is based on deception:

The intention of plundering, of deception, is necessarily present in the background, for since our exchange is a selfish one, on your side as on mine, and since the selfishness of each seeks to get the better of that of the other, we necessarily seek to deceive each other. ${ }^{18}$

However, as Daniel Brudney has pointed out, the focus on plundering and deception is misleading. ${ }^{\text {I9 }}$ Marx's real objection to market exchanges based on individual self-interest is that if I engage in market exchange I do not take a genuine interest in the other's need as such; rather, I see the other's need as an opportunity to further my self-interest. It is not my end to help the other meet his need, but to profit from its existence. Hence, Marx also writes that "we try to impose on each other by bluff, and the more adroit overreaches [übervortheilt] the other. For the totality of the relationship, it is a matter of chance who overreaches whom." ${ }^{20}$ Thus the fact that the exchange is mutually beneficial does not change the fact that the completion achieved through it is mere semblance. As Brudney puts it, under market exchange it is a trivial rather than a vital fact that I have produced for another's use, while, in communist production, it is a vital fact and constitutive of the human good. ${ }^{2 I}$ Under market exchange I do not intend to satisfy the other's need for its own sake; rather I use it purely instrumentally.

In contrast, in communist production we intend to benefit the other, and we do not use each other purely instrumentally. ${ }^{22}$ There is a necessary connection between my ability to realize myself through my labor and the fact that the product of my labor meets your need and vice versa. I must have it as my end to produce something that is useful to you, and you must know that I have this end. As a result, Marx can say that in communist production, I "know myself to be confirmed both in your thought and your love." As Brudney has pointed out, the reference to love here should not be read as implying that in communism subjects stand in intensely affective relationships to each other, but that the structure of human relationships in communism replicates the structure of personal ones.

\footnotetext{
${ }^{17}$ Smith, Wealth of Nations, Bk IV, Ch. 2, 456.

${ }^{18}$ Marx, "Comments on James Mill," 226. Honneth refers to this passage at Freedom's Right, 5I.

19 Cf. Daniel Brudney, Marx's Attempt to Leave Philosophy (Cambridge, MA: Harvard University Press, 1998), I72-73.

${ }^{20}$ Marx, "Comments on James Mill," 226.

${ }^{21}$ Brudney, Marx's Attempt to Leave Philosophy, I8 5.

${ }^{22}$ Brudney, Marx's Attempt to Leave Philosophy, I70.
} 
Just as in friendship or love we give things to each other as gifts in order to express our relatedness, in communist production we produce for each other in order to express our solidarity, which is structurally analogous to friendship and love. ${ }^{23}$ In both cases our own good and the other's good are inseparable. Both Hegel and Honneth model their conceptions of social freedom on friendship and love. As Honneth puts it, Hegel could grasp the market economy "as a new, indirect form of 'being with oneself in the other'." 24 Therefore, we should expect that their conceptions of social cooperation in the market are closer to Marx's than to Smith's.

\section{The reality of social freedom}

Honneth's analysis of the market economy begins with a chapter entitled "The market and morality: a necessary preliminary clarification." 25 The purpose of the chapter is to show that the market economy depends on moral and ethical foundations, that these moral and ethical norms are best understood as intrinsic rather than extrinsic to the market economy, and that the existence of these norms makes the market economy a (potential) sphere of social freedom. Honneth's analysis is strongly indebted to Hegel, and therefore my discussion of it will return to Hegel where necessary. Before I begin, it is worthwhile pointing out one point on which Honneth departs from Hegel, which is very important for my argument. In Hegel's Philosophy of Right the discussion of the market economy takes place in a section of the book entitled "Civil Society," and Hegel makes it clear that civil society encompasses a number of institutions, of which the market economy is only one, albeit a central one. The characteristic feature of civil society is that it is a social sphere that is distinct from political society. In civil society individuals pursue their private ends, whether they are economic or associative. ${ }^{26}$ In contrast, Honneth's Freedom's Right discusses the market economy as a social sphere in its own right. This opens up difficult questions about the boundaries of the market economy which I want to discuss in the remainder of this paper. My argument will be that market institutions, narrowly conceived, make no contribution to social freedom, but often undermine it, and that Honneth obscures this important point due to his broad conception of the market economy.

Honneth defends the existence of moral and ethical foundations of the market through an appeal to "normative functionalism." 27 This is the view that "like any other social sphere, the market also relies upon the moral consent of the participants, such that its existence cannot be explained without reference to the supplementary norms that legitimate the market in the eyes of economic actors." 28 Honneth ascribes this view primarily to Hegel (but also to Durkheim, Karl Polanyi

\footnotetext{
${ }_{23}$ Brudney, Marx's Attempt to Leave Philosophy, I83.

${ }^{24}$ Honneth, Freedom's Right, 46.

${ }^{25}$ Honneth, Freedom's Right, I78-98.

${ }^{26}$ Cf. Michael O. Hardimon, Hegel's Social Philosophy. The Project of Reconciliation (Cambridge: Cambridge University Press, I994), I89-9I.

${ }_{27}$ Honneth, Freedom's Right, I83.

${ }^{28}$ Honneth, Freedom's Right, 184 .
} 
and Talcott Parsons). What exactly are these supplementary norms? Honneth's initial answer, following Hegel (and Durkheim), is that:

the market can only fulfill its function of harmoniously integrating individual economic activities in an unforced manner and by means of contractual relations if it is embedded in feelings of solidarity that precede all contracts and obligate economic actors to treat each other fairly and justly. ${ }^{29}$

Later, in the chapter Honneth formulates three specific conditions for the moral consent of participants to the market economy. First, "the purely individual self-interest constitutive of market behaviour must be able to fulfil the normative condition that all participants can understand it as a suitable means for the complementary realization of their own respective purposes." $3^{\circ}$ That is, market behaviour must make social freedom possible. Second, market institutions must "institutionally reflect these underlying claims to social freedom, thus ensuring that the participants remain aware of these claims." ${ }^{\mathrm{I}}$ Third, "[e]xpressed in terms of recognition, this means that economic actors must have recognized each other as members of a cooperative community before they can grant each other the right to maximise individual utility." ${ }^{22}$ These references to the institutionalization of moral and ethical claims and the need for mutual recognition show once more that the form of social freedom that the market economy must realize is (meant to be) closer to Marx's than Smith's version of completion.

The question is whether Hegel's discussion of the market economy in the Philosophy of Right supports the argument that it realizes social freedom. Initially, Hegel argues that individuals are interdependent because they need others in order to satisfy their own needs, and that they make themselves useful to others in order to meet their own needs. ${ }^{33}$ As a result, individual selfishness serves the common good: "In this dependence and reciprocity of work and the satisfaction of needs, subjective selfishness turns into a contribution to the satisfaction of the needs of everyone else." 34 It is important to note that individuals need not necessarily be conscious of this unintentional result of their self-interested actions. ${ }^{35}$ Like Smith, Hegel believes that the market coordinates need satisfaction by an "invisible hand." In this sense it is at best Smith's version of completion. However, according to Honneth, Hegel does believe that moral and ethical attitudes do have a place in market economy: "the coordination of merely individual material calculations can only succeed if the subjects involved antecedently recognize each other not only legally as parties to a contract, but also morally or ethically as members of a cooperative community." 36

The most natural place to look for these attitudes is in the corporations. In fact, according to Honneth, when it comes to this antecedent recognition

\footnotetext{
29 Honneth, Freedom's Right, I 8 I.

30 Honneth, Freedom's Right, I9I-92.

${ }^{\text {I }}$ Honneth, Freedom's Right, I92.

32 Honneth, Freedom's Right, 192.

33 Hegel, Philosophy of Right, $\S_{1} 8_{3}$, I 87.

34 Hegel, Philosophy of Right, § I 99.

35 Hegel, Philosophy of Right, $\S_{I} 85$.

${ }^{6}$ Honneth, Freedom's Right, I 82.
} 
Hegel "places all his expectations in the prior existence of mutual esteem secured by the "corporations'." 37 In the Philosophy of Right, corporations are discussed at the end of the section on civil society. Corporations are professional associations in which individuals are members in virtue of their particular skills and profession. Corporations regulate these professions and protect their members against the contingencies of life. ${ }^{38}$ Individuals gain honour and recognition through their membership in a corporation; it is foundational of their social identity. ${ }^{39}$ Hegel thinks that corporations have an important role to play in the formation of the ethical attitudes of their members, and at one place he writes that while the family is the first ethical root of the state, the corporation is the second. ${ }^{\circ}$ Most importantly, it is only in corporations that subjects consciously see themselves as engaged in social cooperation ${ }^{4 \mathrm{I}}-$ which is a precondition of social freedom.

In Freedom's Right, Honneth agrees with Hegel that the institutions that are most likely to instil a sense of solidarity in their members are institutions, which, like Hegel's corporations or Durkheim's occupational groups, require discursive mechanisms of will formation that cannot be reduced to economic rationality. In particular, he seems to think that when members of such institutions are concerned with the regulation of behaviour in the market and, therefore, must consider the interests of other market participants, the perspective-switching that this requires "will cause them to take greater account of the underlying principles of their cooperation." ${ }^{2}$ However, Honneth also acknowledges, following Durkheim, that more radical measures may be required to institutionalize principles of fairness, justice and solidarity in the market economy, including the establishment of genuine equality of opportunity through education, the right to meaningful work and restrictions on the accumulation of wealth. ${ }^{43}$

\section{Two problems}

There are at least two problems with this appeal to corporations. First, in the Philosophy of Right, corporations are not part of the market economy but independent institutions of civil society. Thus, for Hegel, corporations cannot make the market economy into a sphere of social freedom (however, corporations may be the reason for why Hegel believes that civil society is a sphere of social freedom). In contrast, Honneth defends a much broader conception of the market economy, according to which the "institutional prerequisites" 44 of the market do belong to it. In my view, Hegel's conception of civil society is more plausible for reasons that will become apparent once we have considered the second problem with the appeal to

\footnotetext{
37 Honneth, Freedom's Right, I9I.

${ }^{38}$ Hegel, Philosophy of Right, \$252.

39 Hegel, Philosophy of Right, \$253.

$4^{\circ}$ Hegel, Philosophy of Right, \$255.

${ }^{4 \mathrm{I}}$ Hegel, Philosophy of Right, $\S_{25} \mathrm{~A}$.

${ }^{42}$ Honneth, Freedom's Right, I93.

${ }_{43}$ Honneth, Freedom's Right, I94.

${ }^{44}$ Honneth, Freedom's Right, I 82.
} 
corporations. This second problem concerns the sources and content of the solidarity that members experience in corporations. According to Hegel and Honneth, the solidarity that members of corporations have for their fellow members is based on their shared interests and their common social status, which their profession bestows upon them. ${ }^{45}$ But these relationships are not market relationships. Members of the same corporations do not produce for each other, and they (typically) do not exchange goods with one another. Therefore, it is not even clear whether members of corporations can be said to complete each other in the sense in which market participants are said to complete each other. But even if corporations were institutions that realize social freedom, it would not follow that the market economy realizes social freedom, because the relationships that members of corporations experience are not mediated by market mechanisms. They are non-market relationships in civil society, and even though they may exist because the market economy exists ${ }^{46}$ they do not depend on it and may exist in non-market societies too.

It should be apparent now, why I find Hegel's conception of civil society more plausible than Honneth's conception of the market economy. Corporations and similar institutions do not institutionalize principles of social freedom in the market economy. Rather, they limit the scope of the market economy from the outside. This view is particularly plausible in the case of institutions which rely on discursive mechanisms of will formation. Market mechanisms and discursive mechanisms of will formation are alternative, and sometimes competing, mechanisms of action coordination. ${ }^{47}$ Honneth believes that some institutions that belong intrinsically to the market economy are based on discursive will formation, and that these institutions create the framework (including the ethical framework) within which market mechanisms operate. But then the question is, why not consider them restrictions imposed on the market economy from the outside? This question is especially pertinent, since discursive will formation is definitive of the political realm in Freedom's Right, ${ }^{48}$ and many, though not all, moral and ethical restrictions that are imposed on the market economy are imposed on it by the state. And the answer to this question is important for two reasons. First, the demonstration that market mechanisms make no contribution to social freedom should limit the appeal of free-market ideologies, because it shows that the benefits of free markets in terms of social freedom are very limited. ${ }^{49}$ Second, the demonstration that state intervention in the market can increase social freedom should legitimize such intervention.

\footnotetext{
45 Cf. also Hardimon, Hegel's Social Philosophy, 197-202. If corporations have employers and employees as members, as Hardimon claims, then their relationship may be an exception.

${ }^{46}$ According to Neuhouser, the bonds of solidarity that one has with members of one's corporation "develop directly out of one's egoistically motivated productive activity and are therefore still grounded in one's role as an independent individual who pursues private ends" (Foundations of Hegel's Social Theory, I37). But this is characteristic of action in civil society in general. What matters for my purposes is that, in corporations, members do not use market mechanisms in the pursuit of their private ends.

47 Cf. Jürgen Habermas, Theory of Communicative Action, Volume 2: A Critique of Functionalist Reason, trans. Thomas McCarthy (Boston: Beacon Press, I987); cf. also Timo Jütten, "Habermas and Markets," Constellations 20, no. 4 (2013): $587-603$.

$4^{8}$ Honneth, Freedom's Right, 254.

49 Of course, nothing I say here denies that free markets may have beneficial effects in terms of individual freedom.
} 
Honneth's reply to this argument seems to be that these restrictions on the market should be seen as intrinsic rather than extrinsic to it, because they are necessary conditions of its proper functioning. If they are absent or ignored, "we can expect not only a disruption of the market mechanism itself, but also a subtle or publicly articulated withdrawal of legitimacy on the part of the population." $5^{\circ}$ Not only will the market no longer satisfy the needs of all market participants, it also will lead to experiences of alienation and anomie among them, because they can no longer understand the market economy as a form of social cooperation that realizes social freedom. However, it seems equally plausible to suggest that market mechanisms have no intrinsic connection to social freedom, and it is only when they are embedded in an ethical framework that they can contribute to it.

There are two reasons for preferring the suggestion that market mechanisms have no intrinsic connection to social freedom. First, some defining principles of markets, such as competition and the determination of prices through supply and demand, are in conflict with some moral and ethical preconditions of social freedom. To give but one example, collective bargaining for wages or minimum wage legislation, which conflict with both of these principles, can be seen as preconditions of social freedom. Without them workers are exposed to the dangers of exploitation and poverty, both of which undermine their status as equals who are engaged in a cooperative endeavour with their employers. Second, it may be argued that market mechanisms encourage market participants to develop motives for action that are incompatible with social freedom. As G.A. Cohen has noted, individuals in a market society typically are motivated to work by a mixture of greed and fear, that is, they see other market participants either as potential sources of enrichment or as threats to their own success. To be sure, individuals may also have other motives to work, including altruistic and cooperative ones, but the market depends crucially on fear and greed..$^{5}$ In order to fulfil its functional role, the efficient material reproduction of society, a market economy requires that employers exercise forms of domination over their workers, which ensures their discipline through threats of unemployment, poverty, and so on. ${ }^{52}$ This domination may be implicit rather than explicit, but it is in the nature of a market economy that it can be exercised at any time if the efficient functioning of production requires it. As a consequence, workers in market societies are motivated by greed and fear, motives which are incompatible with the experience of social freedom in the market economy, which seems to require a concern with others' needs and a non-instrumental interest in meeting these needs.

\section{Normative reconstruction and social freedom}

The question of what is and what is not part of the market economy concerns Honneth throughout his normative reconstruction of the spheres of consumption

\footnotetext{
${ }^{\circ}$ Honneth, Freedom's Right, I9I.

${ }^{5}$ Cf. G.A. Cohen, Why Not Socialism? (Princeton: Princeton University Press, 2009), 40.

${ }^{2}$ On this point see also Nicholas Vrousalis, "Jazz Bands, Camping Trips and Decommodification: G.A. Cohen on Community," Socialist Studies 8, no. I (20I2): I 57. A fuller discussion of this point would have to consider whether Cohen's argument does in fact hold for market socialism. Unfortunately, I do not have the space to discuss this important issue here.
} 
and the labor market. If I am right, then his arguments in these chapters are flawed. In what follows I want to raise additional questions about Honneth's reconstruction, which concern the method of normative reconstruction itself. To begin with, consider his explanation of this method:

Given institutions and practices will be analysed in terms of their normative achievements and recounted in order of their significance for the social embodiment and realization of socially legitimated values. In the context of this procedure, 'reconstruction' thus means that out of the entirety of social routines and institutions, we will only pick out those that are indispensable for reproduction. And because the aims of social reproduction are essentially determined by social values, 'normative' reconstruction means categorizing and ordering these routines and institutions according to the impact of their individual contribution to the stabilization and implementation of these values. ${ }^{53}$

Social freedom is central to Honneth's argument because he identifies freedom as the defining value of modern society, ${ }^{54}$ and, following Hegel, he argues that negative and reflexive freedom are incomplete articulations of the value of freedom and cannot underwrite a theory of social justice. ${ }^{55}$

The question is whether such a reconstruction of the institutions of modern societies according to their contribution to the realization of social freedom does not prejudice the outcome of the analysis. For example, at some points in his analysis Honneth is quite clear that his selection of the material marginalizes precisely those philosophical and political positions which deny that the market is a potential sphere of social freedom, and that all that is needed to realize it are internal corrections: Marx, Marxists and most of the labor movements of the nineteenth century. ${ }^{56}$ But if the material for the normative reconstruction is assembled selectively, how do we know that the right material has been selected? Could Honneth's normative reconstruction not be an ideologically distorted picture of the market economy that ascribes to it a potential for social freedom that in fact it does not possess?

Honneth's defence of the claim that the market economy depends on moral foundations appeals to the consent of market participants, which, in turn, rests on their conviction that market institutions do realize social freedom. He also argues that once subjects begin to doubt the legitimacy of market institutions, they experience alienation and anomie. I want to raise two critical questions about this defence. First, is it not possible that subjects are mistaken about market institutions? As we have seen, social freedom is about subjects completing each other, a form of social cooperation in which your success depends on mine, and mine depends on yours, and where we intend to bring about each other's success. And Honneth points out that, historically speaking, subjects have protested against

\footnotetext{
53 Honneth, Freedom's Right, 6.

54 Honneth, Freedom's Right, I 5.

${ }^{55}$ Honneth defends this controversial claim in the first two Parts of Freedom's Right and also in Axel Honneth,

"The Fabric of Justice: On the Limits of Contemporary Proceduralism," in The I in We. Studies in the Theory of Recognition, trans. Joseph Ganahl, (Cambridge: Polity, 20I2), 35-55.

${ }^{56}$ Honneth, Freedom's Right, 210, 228-29.
} 
market institutions when they have felt that this reciprocity has been undermined. This is one way of understanding the bread riots in the eighteenth century. ${ }^{57}$ However, strictly speaking, what these protests show is at best that subjects believe that market institutions ought to realize social freedom, not that they can do it. ${ }^{58}$ Subjects may think that the market is, in general, a sphere of social freedom but has failed in this case to live up to this potential. If my argument so far is correct, this is a mistake, but subjects may be misled by ideology into believing that the market is, in fact, a sphere of social freedom, or could become one if it lived up to its potential. The importance of this possibility is that popular protest against market outcomes, even when it invokes demands for social freedom, does not necessarily establish that the market is, or can be, a sphere of social freedom.

Second, one may think that when the poor were protesting about the rising prices for corn, they were appealing to the idea of a "fair price" and to precapitalist traditions concerning a right to subsistence, but neither is compatible with the market economy, narrowly conceived. So the protesters were not appealing to any economic principle, but to moral principles which, in their view, should trump economic principles in this case. Therefore, I do not think that the food riots can be construed as an indication that the protesters understood the market economy as a potential sphere of social freedom. Rather, they argued that if it leads to food scarcity and famine, the market should be regulated or replaced with a non-market mechanism of distributing food. Honneth summarizes his argument in this passage:

The 'bread riots' and boycotts of the nineteenth century illustrate that in the eyes of most participants on the market, the prices for certain elementary commodities should not merely be left up to the competition between supply and demand. Therefore, it would not be long before state organs responded to such moral reactions by either legally regulating or subsidizing housing and food. Here as well, therefore, the sphere of consumption rests on general political regulations that, upon closer inspection, express just how much the market economy must meet the normative demand that elementary consumer interests be satisfied. ${ }^{59}$

I just fail to see how this demonstrates that market participants understood the market as a sphere of social freedom. Rather, it suggests the opposite to me. It is because supply and demand - the mechanisms central to the market - do not lead to the satisfaction of elementary consumer interests that political regulation is required.

\section{Social freedom in the labor market}

A similar argument can be made about the sphere of social labor. According to Honneth's normative reconstruction, soon after the emergence of free labor markets workers appealed to the normative principles that they saw as implicit in the capitalist economic order in support of their demands for a right to work, worker

\footnotetext{
57 Honneth, Freedom's Right, 20I-202.

${ }^{8}$ The danger from Honneth's perspective is that this ought is indistinguishable from the abstract ought of formal, proceduralist theories of justice which he criticizes in Freedom's Right.

59 Honneth, Freedom's Right, 209.
} 
safety and basic protections in case of illness. ${ }^{60}$ In particular, workers believed that "the system of contractual freedom normatively implied social conditions under which this freedom could in fact be realized." ${ }^{6 I}$ However, as Honneth also points out, the institutionalization of social welfare policies in the sphere of labor through subjective rights, which realized some of these demands, had a profound de-socializing effect on workers and undermined their collective self-organization. ${ }^{62}$ As a result, the social security that workers gained through the introduction of the welfare state did not transform the sphere of labor into a sphere of social freedom. According to Honneth, the realization of social freedom in the sphere of labor has two conditions: (i) discursive mechanisms through which workers can shape their cooperative activity, ${ }^{63}$ and (ii) the humanization of labor through the avoidance of work that is merely mechanical, repetitive and devoid of challenges. ${ }^{64}$

Honneth derives the first condition from Durkheim's work on occupational groups. Social freedom requires that all participants in the labor market are able to grasp their activity as a cooperative endeavour for the common good that transcends egoistic and strategic behaviour, and this requires that workers can influence employers' decisions. ${ }^{65}$ According to Honneth's normative reconstruction, the principle of codetermination (Mitbestimmung) is an example of this. Originally introduced during the First World War when increasing demand gave unions the power to negotiate wages and working conditions with employers, co-determination became a permanent demand of labor unions. After the Second World War it was institutionalized to various degrees in many European countries, most extensively in Germany. ${ }^{66}$

Without denying the progressive aspects of co-determination, it is questionable whether it realizes social freedom in the labor market. Co-determination recognizes the power relations that obtain in the economy between workers and employers. It serves the self-interest of both sides; the workers, through their unions, gain some influence on decision-making, while employers reap the benefits of industrial peace and the convenience and security of regulated negotiation procedures for the organization of labor (and some other business decisions). ${ }^{67}$ Thus workers and employers complete each other only in the very weak sense that each uses the other in order to achieve their aims, rather than in the stronger sense that they deliberate about the cooperative pursuit of shared aims. But it is the latter, rather than the former, that is required for the realization of social freedom. In any case, Honneth notes that co-determination, like the humanization of work, ultimately reduces competition, ${ }^{68}$ and this suggests that it is in conflict with a defining principle of the market mechanism, rather than an intrinsic part of it.

\footnotetext{
${ }^{60}$ Honneth, Freedom's Right, 227.

${ }^{61}$ Honneth, Freedom's Right, 228.

${ }^{62}$ Honneth, Freedom's Right, 23 I.

${ }^{63}$ Honneth, Freedom's Right, 229, 232.

${ }^{64}$ Honneth, Freedom's Right, 237.

${ }^{65}$ Honneth, Freedom's Right, 232.

${ }^{66}$ Honneth, Freedom's Right, 238-4I.

${ }^{67}$ For more details on the German case see Sigurt Vitols, "Varieties of Corporate Governance: Comparing Germany and the UK," in Varieties of Capitalism: The Institutional Foundations of Comparative Advantage, ed. Peter A. Hall \& David Soskice (Oxford: Oxford University Press, 200I), 337-6I.

${ }^{68}$ Honneth, Freedom's Right, 24I.
} 


\section{The humanization of work}

Honneth's second condition for the realization of social freedom in the sphere of labor is the humanization of work. He notes that "work that requires neither skill nor initiative deprives workers from seeing themselves as making a valuable contribution to social cooperation." 69 In general, work is dehumanizing if it is repetitive or monotonous, induces time-pressure and requires no creativity or initiative. ${ }^{70}$ Therefore, dehumanizing work is not limited to manufacturing but also can be found in the service sector. ${ }^{7 \mathrm{I}}$ This is so, because the capitalist recognition order distributes social esteem according to an achievement principle that prizes intellectual creativity and initiative above all else. ${ }^{72}$ The result is a "vertical division" within the labor force, which leads to the "collective degradation" of the traditional industrial proletariat and the lower strata of the service sector in comparison with highly skilled and specialized workers in both sectors. ${ }^{73}$

Honneth's concern with the humanization of work is understandable, but it is also perplexing, given his earlier discussion of this problem. In a paper on work and recognition Honneth had argued that external criticism of the social organization of labor, which draws on a craft conception of labor was "too weakly linked to the demands of economically organized labor," to have a real influence on the social struggles of the labor movement. ${ }^{74}$ Moreover, Honneth had argued that utopian ideals of labor based on craftsmanship and inspired by aesthetic and romantic ideals cannot provide a normative foundation for the critique of the existing social organization of labor, because "it is a fallacy to claim that all socially necessary activities are naturally constituted along the lines of an organic and holistic form such as craftsmanship." 75 If this is right, then the external criticism of the social organization of labor is based on "mere wishes [Sollensforderungen]," ${ }^{76}$ that is, exactly the abstract form of social criticism that Honneth sets out to criticize in Freedom's Right. ${ }^{77}$ Unless Honneth has changed his mind about the craft conception of labor, then, the conclusion to be drawn from this argument should be that, if the realization of social freedom in the labor market requires the humanization of work, then the labor market cannot be a sphere of social freedom, regardless of what philosophers, sociologists and the workers themselves may have believed in the past.

In his earlier paper on work and recognition, Honneth had suggested a weaker account of the humanization of work as an alternative to the craft conception of

\footnotetext{
69 Honneth, Freedom's Right, 237.

70 Honneth, Freedom's Right, 237, 24I.

${ }^{71}$ Honneth, Freedom's Right, 243.

${ }^{72}$ Honneth, Freedom's Right, 24I. On this point see also Axel Honneth, "Redistribution as Recognition: A Response to Nancy Fraser," Nancy Fraser and Axel Honneth, in Redistribution or Recognition? A Political-Philosophical Exchange, I I0-97 (London and New York: Verso, 2003), I 50-59.

${ }^{73}$ Honneth, Freedom's Right, 244.

${ }^{74}$ Axel Honneth, "Work and Recognition: A Redefinition," in The Philosophy of Recognition: Historical and Contemporary Perspectives, ed. Hans-Christoph Schmidt am Busch \& Christopher F. Zurn, 222-39 (Lanham, MD: Lexington Books, 2010), 226.

75 Honneth, "Work and Recognition," 228.

${ }^{76}$ Honneth, "Work and Recognition," 226.

77 Honneth, Freedom's Right, I-2.
} 
labor in order to avoid this conclusion. Specifically, he had argued that the existing social organization of work is based on moral norms that are the basis for its legitimacy in the eyes of workers. Even where those norms are violated in practice, their existence serves as a normative standard for internal social criticism. ${ }^{78}$ In the light of Honneth's criticism of the craft conception of labor, the content of these norms does not concern the form of labor but its social organization. Drawing on Hegel and Durkheim, Honneth argued that for the capitalist labor market to be legitimate it must provide workers with a living wage and recognize that workers make through the exercise of their skills a contribution to the common good. Moreover, the social division of labor must be fair and transparent, and equal opportunities must exist for all. ${ }^{79}$ It is only under those conditions, Honneth argued, that workers could experience their work as meaningful. In Freedom's Right Honneth seems to retain these commitments along with those to codetermination and the humanization of work discussed above, although they now are framed more explicitly in terms of social cooperation and solidarity. ${ }^{80}$

The problem with these commitments is similar to those discussed above. First, it seems that many of the necessary conditions for the labor market being a sphere of social freedom are restrictions on the operation of the free market. I already have shown that the living wage is not a concept that is intrinsic to the market mechanism, and the same is true of the complex demands that Honneth places on the capitalist recognition order. In particular, there is no reason internal to the economy that the deployment of one's skills for the common good should be recognized by social esteem, or that the division of labor should be organized fairly and transparently. To be sure, all of these demands are desirable, and Honneth is right to criticize the fact that they have lost their force in the political realm, but it is not clear to me that this is best characterized as a misdevelopment of the market economy, considered as a sphere of social freedom, rather than as the free market's coming into its own.

At the end of his discussion of the labor market Honneth acknowledges that we may have experienced a change in attitudes towards the market from the view that it ought to be understood as a sphere of social freedom to the view that it is a sphere of merely individual freedom. He also claims that we may never know the truth of the matter, because ultimately it cannot be empirically proven. ${ }^{8 \mathrm{I}}$ Indeed, as he pointed out earlier in his discussion, the conflict about the normative status of the labor market is an "interpretive conflict." ${ }^{82}$ In his earlier paper on work and recognition Honneth had suggested that we may be able to adjudicate on this conflict in favour of an understanding of the market as a morally embedded sphere of social integration because of the ongoing labor struggles against the social organization of labor. ${ }^{83}$ However, we can see now that this option is no longer open to Honneth for two reasons. First, workers could be wrong about the

\footnotetext{
${ }^{78}$ Honneth, "Work and Recognition," 230, 233.

79 Honneth, "Work and Recognition," 233, 235.

${ }^{80}$ Honneth, Freedom's Right, I8 8-85, I9I-95.

8I Honneth, Freedom's Right, 250.

${ }^{82}$ Honneth, Freedom's Right, 228.

${ }^{83}$ Honneth, "Work and Recognition," 236-37.
} 
potential for social freedom in the market economy, just as the bread rioters might have been wrong in the eighteenth century (see §VI). Second, labor struggles often are struggles against the power of market mechanisms that appeal to non-market norms in order to justify their claims.

\section{Conclusion}

The purpose of this paper was to examine the plausibility of Honneth's claim that the market is a potential sphere of social freedom. I have suggested that social freedom is a demanding ideal which requires, in the market economy, that individuals complete each other by satisfying each other's needs, and that they must do so intentionally and not purely for instrumental reasons. I have argued that market mechanisms on their own do not meet these requirements, and that there is nothing intrinsic in the market economy that ensures the social freedom of market participants. If anything, it undermines it. Of course, it frequently happens that our interests complement one another so that we can complete each other through the medium of market exchange. But there is nothing in the nature of capitalist production and exchange that ensures regard for the needs of others in the face of monetary incentives to ignore those needs. If we value social freedom, we therefore must restrict the market from the outside. I have also argued that Honneth's normative reconstruction of the market economy cannot establish the existence of social freedom in it through an appeal to people's normative expectations that it does.

These results are important for critical social theory. Over the last thirty-five years many critical theorists have made their peace with markets, because they think that markets are functionally efficient, because there are no alternatives or, in Honneth's case, because they do think that markets can contribute to social freedom. However, his own analysis in Freedom's Right shows that markets currently do not contribute to social freedom, and the question is how to react to this analysis in terms of the development of critical social theory. Politically, it may well be best to pursue the reformist ideas implicit in Freedom's Right: to reverse the individualization and responsibilization that stifles political action and social struggles in the spheres of consumption and production. ${ }^{84}$ But philosophically, it is equally important to critically examine in a lot more detail the extent to which individualization and responsibilization are intrinsically related to the use of market mechanisms in the organization of social labor. My suspicion is that they are so tightly related that it is misguided to speak of neoliberalism and financialization as misdevelopments in the sphere of the market economy at all. Rather, they seem to be the logical conclusion of the very idea of market mechanisms. And that is why these mechanisms cannot contribute to social freedom.

\section{Acknowledgements}

I presented an earlier version of this paper at University College Dublin in March 2OI4, and at the joint Essex-Oxford symposium on Freedom's Right at the Institute

${ }^{84}$ Honneth, Freedom's Right, 248-53. 
of Philosophy, London, in June 20I4. Many thanks to these audiences and especially to Axel Honneth for valuable comments. I also would like to thank Fabian Freyenhagen and Jörg Schaub for written comments on a later version of the paper.

\section{References}

Brudney, D. Marx's Attempt to Leave Philosophy. Cambridge, MA: Harvard University Press, I998.

Cohen, G. A. Why Not Socialism? Princeton: Princeton University Press, 2009.

Habermas, J. Theory of Communicative Action, Volume 2: A Critique of Functionalist Reason, translated by

T. McCarthy. Boston: Beacon Press, 1987.

Hardimon, M. O. Hegel's Social Philosophv. The Project of Reconciliation. Cambridge: Cambridge University Press, I994.

Hegel, G. W. F. Elements of the Philosophy of Right, translated by H. B. Nisbet, edited by A. W. Wood. Cambridge: Cambridge University Press, I99I.

Honneth, A. "Redistribution as Recognition: A Response to Nancy Fraser." In Redistribution or Recognition? A Political-Philosophical Exchange, N. Fraser and A. Honneth, Iro-97. London and New York: Verso, 2003.

Honneth, A. "Work and Recognition: A Redefinition." In The Philosophy of Recognition: Historical and Contemporary Perspectives, edited by H.-C. Schmidt am Busch and C. F. Zurn, 222-39. Lanham, MD: Lexington Books, 2010 .

Honneth, A. Das Recht der Freiheit: Grundriß einer demokratischen Sittlichkeit. Berlin: Suhrkamp, 20 I I.

Honneth, A. "The Fabric of Justice: On the Limits of Contemporary Proceduralism." In The I in We. Studies in the Theory of Recognition, translated by J. Ganahl, 35-55. Cambridge: Polity, $20 \mathrm{I} 2$.

Honneth, A. Freedom's Right: The Social Foundations of Democratic Life, translated by J. Ganahl. Cambridge: Polity, 20I4.

Jütten, T. "Habermas and Markets." Constellations, 20 (2013): 587-603.

Neuhouser, F. Foundations of Hegel's Social Theory: Actualizing Freedom. Cambridge, MA: Harvard University Press, 2000.

Marx, K. “Comments on James Mill, Éléments D’économie Politique.” In Collected Works Vol. 3, K. Marx and F. Engels. New York: International Publishers, I975.

Smith, A. An Inquiry Into the Nature and Causes of the Wealth of Nations, edited by R. H. Campbell and A. S. Skinner. Indianapolis, IN: Liberty Fund, I976.

Vitols, S. "Varieties of Corporate Governance: Comparing Germany and the UK." In Varieties of Capitalism: The Institutional Foundations of Comparative Advantage, edited by P. A. Hall and D. Soskice, 337-6I. Oxford: Oxford University Press, 200I.

Vrousalis, N. "Jazz Bands, Camping Trips and Decommodification: G.A. Cohen on Community." Socialist Studies 8 (2OI2): I4I-63.

\section{Notes on contributor}

Timo Jütten is a Lecturer in Philosophy at the University of Essex, UK. He works on social and political philosophy, especially critical social theory, and his current research is on the moral limit of markets. His papers have appeared in the European Journal of Philosophy, Inquiry and International Journal of Philosophical Studies. He recently co-edited a special section of Constellations on Habermas' Theory of Communicative Action (with Maeve Cooke).

Correspondence to: tjuetten@essex.ac.uk. 